\title{
Bioactive Metabolites from the Caribbean Sponge Aka coralliphagum
}

\author{
Achim Grube, ${ }^{\dagger}$ Michael Assmann, ${ }^{\dagger}$ Ellen Lichte, ${ }^{\dagger}$ Florenz Sasse,${ }^{\ddagger}$ Joseph R. Pawlik, ${ }^{\perp}$ and Matthias Köck*,† \\ Alfred-Wegener-Institut für Polar- und Meeresforschung in der Helmholtz-Gemeinschaft, Am Handelshafen 12, \\ D-27570 Bremerhaven, Germany, Helmholtz Centre for Infection Research, Inhoffenstrasse 7, D-38124 Braunschweig, Germany, and Center \\ for Marine Science, University of North Carolina at Wilmington, 5600 Marvin K. Moss Lane, Wilmington, North Carolina 28409
}

Received June 28, 2006

The chemistry of the burrowing sponge Aka coralliphagum was investigated to identify chemically labile secondary
metabolites. The HPLC-MS analysis of the two growth forms typica and incrustans revealed different metabolites. The
previously unknown sulfated compounds siphonodictyals B1 to B3 (6-8), corallidictyals C (9) and D (10), and
siphonodictyal G (11) were isolated, and their structures were elucidated by NMR and MS experiments. The compounds
were tested in a DPPH assay, in antimicrobial assays against bacteria, yeasts, and fungi, and in antiproliferation assays
using cultures of mouse fibroblasts. The biological activity was linked to the presence of the ortho-hydroquinone moiety.

The burrowing sponge Aka coralliphagum (=Siphonodictyon coralliphagum) is a bright yellow colored sponge that burrows into corals. Four distinct morphological growth forms have been described for Aka coralliphagum from the Caribbean: forma typica, f. tubulosa, f. obruta, and f. incrustans. ${ }^{1}$ Several bioactive sesquiterpene hydroquinones, such as the siphonodictyals $(\mathrm{B}, \mathbf{1})$ and siphonodictyols, ${ }^{2}$ were obtained from the forms tubulosa and typica. Although the isolation of labile compounds such as siphonodictyols $\mathrm{G}$ (2) and $\mathrm{H}$ (3) suggested the existence of additional sulfated phenolic compounds in A. coralliphagum, compounds such as the siphonodictyals were isolated without respect to the occurrence of sulfated metabolites. Past isolation and purification methods did not account for the problem of compound hydrolysis. ${ }^{2 a, b}$ This paper describes the isolation, structure elucidation, and biological testing of the new, labile metabolites siphonodictyals B1 to B3 $(\mathbf{6}-\mathbf{8})$, corallidictyals C (9) and D (10), and siphonodictyal G (11) from the Aka growth form incrustans. In order to compare the secondary metabolites of the two growth forms incrustans and typica, an HPLC analysis of their crude extracts was performed. These two forms of $A k a$ occur in different habitats, with typica predominating on shallow water reefs (10-15 m) while incrustans occurs on deep water vertical slopes $(20-25 \mathrm{~m})$. It was deemed important to isolate the labile natural products of these two growth forms in their naturally occurring forms in order to understand more about their biological and ecological function.

\section{Results and Discussion}

Extracts of sponge samples were investigated by an HPLC-MS screening. The two growth forms of Aka coralliphagum (typica and incrustans) showed differences in HPLC fingerprints and their major metabolites (Figure 1). While forma typica contained more polar compounds (shorter retention times), forma incrustans contained three main compounds with a less polar character. Further characterization by HPLC-API-CID-MS/MS showed a single or double sulfation of compounds with shorter retention times. This was deduced by loss of $\mathrm{m} / \mathrm{z} 80$ under MS/MS conditions and detection of a $\left[\mathrm{SO}_{3}\right]^{-}$ion at $m / z 80$ (see Supporting Information) $)^{3}$ as well as a sulfur-specific isotopic pattern. These results indicate that the two growth forms have considerable differences in their secondary metabolite compositions. The isolation and structure elucidation of compounds from the growth form incrustans is discussed in detail below. Due to the instability of these compounds,

* To whom correspondence should be addressed. Tel: +49-47148311497. Fax: +49-471-48311425. E-mail: mkoeck@awi.de.

$\dagger$ Alfred-Wegener-Institut für Polar- und Meeresforschung.

Helmholtz Centre for Infection Research (HZI)

$\perp$ University of North Carolina at Wilmington.

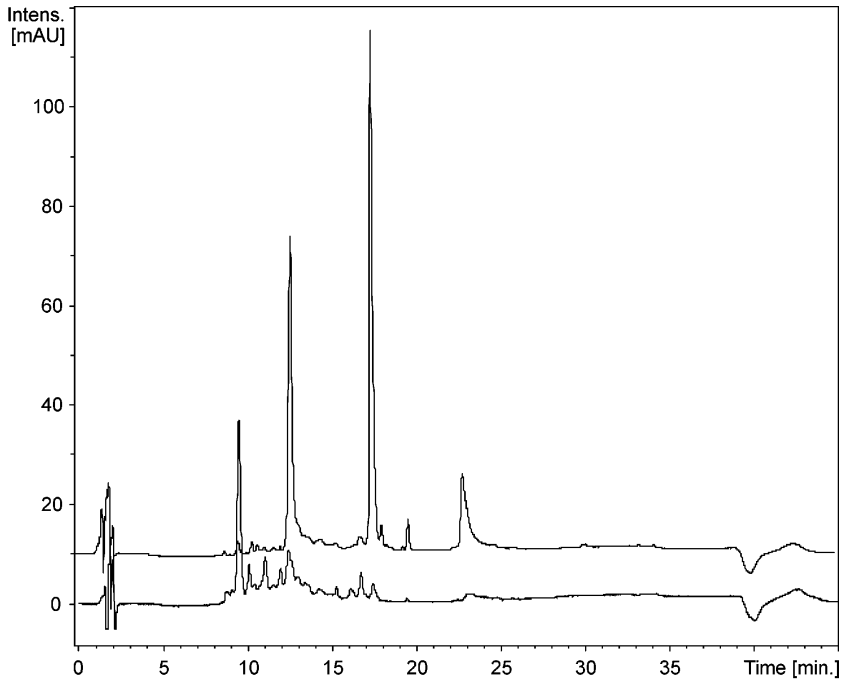

Figure 1. HPLC UV traces $(260 \mathrm{~nm})$ of crude extracts of $A \mathrm{ka}$ coralliphagum. The growth form incrustans (upper line) contains three main metabolites, whereas the growth form typica (lower line) clearly contains one main metabolite with shorter retention time (HPLC conditions are given in the Experimental Section).

a gentle extraction and purification protocol had to be applied. An overnight extraction in $\mathrm{MeOH}$ and a direct purification of the crude extract by preparative HPLC $\left(\mathrm{MeCN} / \mathrm{H}_{2} \mathrm{O}\right.$ gradient) was chosen. All solvents were free of acid to avoid hydrolysis of compounds.

The structure elucidation was based on 1D and 2D NMR, as well as MS/MS experiments. Comparison of molecular masses from HPLC-MS screening and the NMR chemical shifts with data of known compounds from the literature revealed the compounds siphonodictyal B (1), ${ }^{2 \mathrm{a}}$ siphonodictyol G (2), ${ }^{2 \mathrm{~b}}$ and corallidictyal A (4) and corallidictyal $\mathrm{B}(\mathbf{5})^{4}$ in minor concentrations. The ${ }^{1} \mathrm{H}$ and ${ }^{13} \mathrm{C}$ NMR chemical shifts for all isolated compounds are given in Tables 1 and 2. One major compound from incrustans was isolated: a molecule (6) with a highly accurate mass of 544.1680 $[\mathrm{M}-\mathrm{H}]^{-}$, indicating the molecular formula $\mathrm{C}_{24} \mathrm{H}_{35} \mathrm{NO}_{9} \mathrm{~S}_{2}$ with eight degrees of unsaturation. Under MS/MS conditions, the loss of $80 \mathrm{amu}$ was observed, indicating a sulfate ester group. The ${ }^{13} \mathrm{C}$ NMR spectrum displayed nine signals in the area of olefinic/ aromatic carbon atoms and 15 signals in the aliphatic region. The edited HSQC spectrum indicated four methyl and seven methylene groups. Two of these methylene groups belong to an isolated spin system. The aromatic ring system including the imine carbon C-22 
Table 1. ${ }^{13} \mathrm{C}$ NMR Data of Isolated Compounds Recorded in DMSO- $d_{6}{ }^{a}$

\begin{tabular}{|c|c|c|c|c|c|c|c|c|c|}
\hline no. & $\mathbf{1}^{b}$ & 1 & 2 & 6 & 7 & 8 & 9 & 10 & 11 \\
\hline 1 & 39.2 & 39.1 & 22.6 & 39.3 & 39.0 & 39.1 & 30.5 & 30.7 & 22.6 \\
\hline 2 & 19.4 & $19.0^{c}$ & 27.5 & $19.0^{d}$ & $19.0^{e}$ & $19.1^{f}$ & 17.7 & 17.7 & 27.6 \\
\hline 3 & 42.2 & 41.9 & 32.5 & 42.1 & 42.0 & 42.0 & 41.2 & 41.2 & 32.4 \\
\hline 4 & 34.1 & 33.0 & 159.4 & 33.6 & 33.6 & 33.6 & 32.6 & 32.9 & 159.3 \\
\hline 5 & 52.4 & 49.0 & 39.6 & 48.1 & 48.4 & 48.6 & 47.1 & 46.1 & 39.6 \\
\hline 6 & 21.7 & $19.4^{c}$ & 36.3 & $19.0^{d}$ & $19.2^{e}$ & $19.3^{f}$ & 20.6 & 20.9 & 36.3 \\
\hline 7 & 34.8 & 31.2 & 27.3 & 30.2 & 30.6 & 31.0 & 30.2 & 30.7 & 27.2 \\
\hline 8 & 33.9 & 31.7 & 35.7 & 31.1 & 31.3 & 31.4 & 34.5 & 36.4 & 35.9 \\
\hline 9 & 165.8 & 157.0 & 41.4 & 153.7 & 155.6 & 155.8 & 99.8 & 98.2 & 41.6 \\
\hline 10 & 41.9 & 40.3 & 47.3 & 40.1 & 40.3 & 40.4 & 43.0 & 41.9 & 47.5 \\
\hline 11 & 21.2 & 21.4 & 102.8 & 21.5 & 21.5 & 21.5 & 21.4 & 21.7 & 103.0 \\
\hline 12 & 33.2 & 33.6 & 20.2 & 33.0 & 33.0 & 33.0 & 33.1 & 33.2 & 20.2 \\
\hline 13 & 21.1 & 21.9 & 17.5 & 22.1 & 22.2 & 22.0 & 14.6 & 15.4 & 17.8 \\
\hline 14 & 22.5 & 22.9 & 17.6 & 23.2 & 23.0 & 22.8 & 14.9 & 15.7 & 17.5 \\
\hline 15 & 109.3 & 113.4 & 37.4 & 117.4 & 116.1 & 115.8 & 29.1 & 32.8 & 37.1 \\
\hline 16 & 116.6 & 116.6 & 132.9 & 118.0 & 124.9 & & 117.1 & 116.8 & 134.6 \\
\hline 17 & 123.6 & 126.2 & 139.5 & 117.6 & 123.8 & 130.0 & 120.5 & 120.6 & 145.9 \\
\hline 18 & 136.9 & 136.1 & 149.5 & 143.8 & 140.8 & 136.7 & 137.3 & 137.4 & 150.7 \\
\hline 19 & 147.5 & 147.8 & 113.9 & 160.3 & 147.9 & 151.1 & 147.0 & 146.9 & 116.7 \\
\hline 20 & 109.0 & 110.2 & 138.0 & 110.1 & 115.5 & 115.7 & 106.1 & 106.1 & 132.1 \\
\hline 21 & 148.4 & 151.2 & 121.0 & 141.8 & 144.6 & 148.0 & 155.0 & 155.7 & 124.4 \\
\hline 22 & 194.5 & 194.8 & 62.7 & 163.8 & 197.3 & 196.8 & 191.7 & 191.9 & 192.2 \\
\hline $1^{\prime}$ & & & & 50.4 & & & & & \\
\hline $2^{\prime}$ & & & & 50.9 & & & & & \\
\hline
\end{tabular}

${ }^{a}{ }^{13} \mathrm{C}$ chemical shifts $[\mathrm{ppm}]$ are referenced to the DMSO- $d_{6}$ signal (39.5 ppm). ${ }^{b}{ }^{13} \mathrm{C}$ chemical shifts $[\mathrm{ppm}]$ were measured in $\mathrm{CDCl}_{3}$ and are referenced to the $\mathrm{CDCl}_{3}$ signal $(77.0 \mathrm{ppm})$. All formerly published shifts were measured in $\mathrm{CDCl}_{3}$. c,d,e,f Assignments may be interchanged.

accounts for five of the eight degrees of unsaturation, suggesting a bicyclic sesquiterpene unit with one double bond for the rest of the molecule. Owing to the nature of the co-occurring metabolites, the decalin system was supported by comparison of the ${ }^{13} \mathrm{C} N M R$ data of $\mathbf{1}$ and $\mathbf{6}$.

The sesquiterpene unit of $\mathbf{6}$ was identified by ${ }^{1} \mathrm{H},{ }^{1} \mathrm{H}-\mathrm{COSY}$, ${ }^{1} \mathrm{H},{ }^{13} \mathrm{C}-\mathrm{HMBC}$, and 1,1-ADEQUATE experiments. Starting from position 8, HMBC correlations from $\mathrm{H}-8$ to $\mathrm{C}-6, \mathrm{C}-7, \mathrm{C}-9, \mathrm{C}-13$, and $\mathrm{C}-15$ as well as COSY correlations from $\mathrm{H}-8$ to $\mathrm{H}-7$ and $\mathrm{H}-13$ were observed. In addition, with 1,1-ADEQUATE correlations from H-8 to C-7, C-9, and C-13, from H-6 to C-5 and C-7, and from $\mathrm{H}-15$ to $\mathrm{C}-9$, the structure of one-half of ring B was supported, including the connection between the aliphatic and aromatic moiety. Because the ${ }^{1} \mathrm{H}$ shifts of $\mathrm{H}-1, \mathrm{H}-3, \mathrm{H}-5$, and $\mathrm{H}-7$ were overlapped, other separated signals like the two methyl groups at position 12 and 14 had to be used for elucidation of ring A. HMBC correlations from $\mathrm{H}-14$ to C-1, C-5, C-9, and C-10 and from H-12 to C-2, C-3, $\mathrm{C}-4, \mathrm{C}-5$, and $\mathrm{C}-11$ as well as 1,1-ADEQUATE correlations from $\mathrm{H}-11 / \mathrm{H}-12$ to $\mathrm{C} 4$ and $\mathrm{H}-2$ to $\mathrm{C}-1$ and $\mathrm{C}-3$ assisted the structure elucidation of ring $\mathrm{A}$ of the sesquiterpene moiety (Figure 2). Because there were $10 \mathrm{HMBC}$ correlations from $\mathrm{H}-15$ to the sesquiterpene system as well as to the aromatic moiety, carbon C-15 must form the connection between these two sections.

Two methylene groups of the molecule belong to a separated spin system of which one showed a ${ }^{1} \mathrm{H},{ }^{15} \mathrm{~N}-\mathrm{HMBC}$ and a COSY correlation to the protonated nitrogen. COSY correlations between these two methylene groups suggested a $\mathrm{RNH}-\mathrm{CH}_{2}-\mathrm{CH}_{2}-\mathrm{R}$ moiety. To identify this part of the molecule, a hydrolysis reaction was carried out. TLC analysis revealed taurine as the main product, suggesting an imine bond in molecule $\mathbf{6}$, which was further supported by a downfield shift of C-22 in contrast to $\mathbf{1}$ or $\mathbf{7}$.

Analysis of the HSQC spectrum displayed three olefinic protons for position 15, 17, and 22 and one phenolic proton, due to the lack of a correlation at $8.23 \mathrm{ppm}$. Because the molecular formula contains nine oxygen atoms, of which seven are included in sulfate and sulfonic acid groups and one is included in a phenolic hydroxyl group, one oxygen atom remains. A phenolate ion was indicated by the occurrence of one protonated nitrogen atom, one remaining oxygen atom, the absence of a second phenolic proton, and the aromatic ${ }^{13} \mathrm{C}$ shifts. In contrast to $\mathbf{1}$, the ${ }^{13} \mathrm{C}$ chemical shift of $\mathrm{C}-19$ is shifted downfield, which indicated a change from phenol to phenolate. ${ }^{5}$ In this case the sulfate ester group had to be located at the quaternary carbon $\mathrm{C}-21$. HMBC correlations from $\mathrm{OH}-18$ to C-17, C-18, C-19, and C-20 in combination with 1,1-ADEQUATE correlations from $\mathrm{H}-17$ to $\mathrm{C}-18$ and $\mathrm{H}-22$ to $\mathrm{C}-20$ assigned the constitution from $\mathrm{C}-17$ to $\mathrm{C}-20$ and $\mathrm{C}-22$ in the aromatic moiety.

Table 2. ${ }^{1} \mathrm{H}$ NMR Data of Isolated Compounds Recorded in DMSO- $d_{6}{ }^{a}$

\begin{tabular}{|c|c|c|c|c|c|c|c|c|}
\hline no. & 1 & 2 & 6 & 7 & 8 & 9 & 10 & 11 \\
\hline 1 & $1.78 / 1.40$ & $2.08 / 1.46$ & $1.84 / 1.35$ & $1.83 / 1.36$ & $1.83 / 1.39$ & $1.44 / 1.16$ & $1.52 / 1.30$ & $2.11 / 1.50$ \\
\hline 2 & $1.63 / 1.49^{b}$ & $1.82 / 1.33$ & $1.61 / 1.47$ & $1.70 / 1.48$ & $1.63 / 1.48^{c}$ & $1.52 / 1.34$ & $1.52 / 1.34^{d}$ & $1.86 / 1.33$ \\
\hline 3 & $1.38 / 1.16$ & $2.28 / 2.03$ & $1.38 / 1.15$ & $1.39 / 1.16$ & $1.38 / 1.17$ & $1.32 / 1.11$ & $1.32 / 1.11$ & $2.28 / 2.03$ \\
\hline \multicolumn{9}{|l|}{4} \\
\hline 5 & 1.30 & & 1.35 & 1.34 & 1.34 & 1.05 & 1.59 & \\
\hline 6 & $1.71 / 1.49^{b}$ & $1.39 / 1.08$ & 1.71 & $1.70 / 1.48$ & $1.71 / 1.48^{c}$ & $1.48 / 1.37$ & $1.57 / 1.37$ & $1.39 / 1.05$ \\
\hline 7 & $1.72 / 1.34$ & $1.82 / 1.33$ & $1.68 / 1.35$ & $1.70 / 1.35$ & $1.69 / 1.34$ & $1.63 / 1.05$ & $1.52 / 1.30^{d}$ & 1.35 \\
\hline 8 & 2.62 & 1.23 & 2.62 & 2.59 & 2.59 & 2.18 & 1.77 & 1.15 \\
\hline \multicolumn{9}{|l|}{9} \\
\hline 10 & & 0.86 & & & & & & 0.78 \\
\hline 11 & 0.89 & $4.39 / 4.32$ & 0.88 & 0.89 & 0.89 & 0.83 & 0.82 & $4.37 / 4.30$ \\
\hline 12 & 0.86 & 1.01 & 0.85 & 0.86 & 0.86 & 0.86 & 0.88 & 1.00 \\
\hline 13 & 0.89 & 0.98 & 0.90 & 0.89 & 0.86 & 0.69 & 0.67 & 1.00 \\
\hline 14 & 1.12 & 0.79 & 1.11 & 1.14 & 1.14 & 1.13 & 0.93 & 0.81 \\
\hline 15 & 6.04 & $2.66 / 2.61$ & 6.43 & 6.46 & 6.42 & $3.06 / 2.85$ & $3.10 / 2.71$ & $2.78 / 2.70$ \\
\hline \multicolumn{9}{|l|}{16} \\
\hline 17 & 6.85 & & 6.50 & 6.87 & 7.52 & 6.94 & 6.91 & \\
\hline \multicolumn{9}{|l|}{18} \\
\hline 19 & & 6.62 & & & & & & 7.21 \\
\hline \multicolumn{9}{|l|}{20} \\
\hline 21 & & 6.49 & & & & & & 7.12 \\
\hline 22 & 10.26 & 4.33 & 8.60 & 10.10 & 10.11 & 10.09 & 10.15 & 9.82 \\
\hline $1^{\prime}$ & & & 3.82 & & & & & \\
\hline $2^{\prime}$ & & & 2.80 & & & & & \\
\hline $18-\mathrm{OH}$ & 10.03 & 8.80 & 8.23 & 9.13 & & 8.66 & 8.65 & 9.13 \\
\hline $19-\mathrm{OH}$ & 9.00 & & & 11.40 & 11.40 & 10.53 & 10.55 & \\
\hline $21-\mathrm{OH}$ & 10.90 & & & & & & & \\
\hline $22-\mathrm{OH}$ & & 5.04 & & & & & & \\
\hline $22-\mathrm{NH}$ & & & 14.03 & & & & & \\
\hline
\end{tabular}

${ }^{a}{ }^{1} \mathrm{H}$ chemical shifts $[\mathrm{ppm}]$ are referenced to the DMSO- $d_{6}$ signal $(2.50 \mathrm{ppm}) .{ }^{b, c, d}$ Assignments may be interchanged due to an overlapping of signals. 
Chart 1. Structure Formulas of Compounds 1-12 Isolated from Aka coralliphagum (growth form incrustans) ${ }^{a}$<smiles>CC1CCC2C(C)(C)CCC[C@]2(C)/C(=C/c2cc(O)c(O)c(C=O)c2O)C1C</smiles><smiles>CCCC1(C)C(C)CCC2(C)OC3=C(C=O)C(=O)C(O)=CC3=C[C@@H]21</smiles>

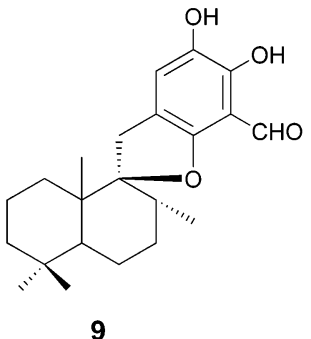<smiles>C=C1CCCC2[C@]1(C)CC[C@@H](C)[C@@]2(C)Cc1cc(CO)cc(O)c1OS(=O)(=O)O</smiles>

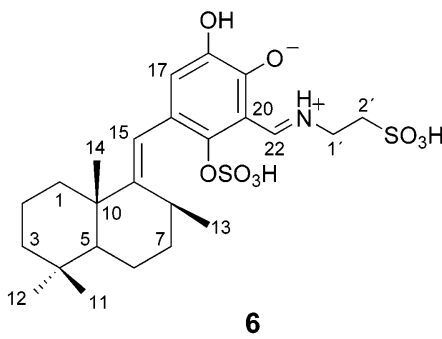

6<smiles>CC1=C(Cc2cc(CO)cc(O)c2OS(=O)(=O)O)[C@@]2(C)CCCC(C)(C)C2CC1</smiles><smiles>CC1CCC2C(C)(C)CCC[C@]2(C)/C1=C\c1cc(O)c(O)c(C=O)c1OS(=O)(=O)O</smiles>

7

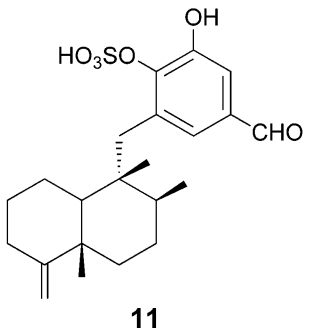<smiles>CC1CCC2C(C)(C)CCC[C@]2(C)[C@]12C=C1C=C(O)C(=O)C(C=O)=C1O2</smiles><smiles>CC1CCC2C(C)(C)CCC[C@]2(C)/C1=C\c1cc(OS(=O)(=O)O)c(O)c(O)c1OS(=O)(=O)O</smiles>

8



a The occurrence of the phenolate ion in $\mathbf{6}$ was confirmed by NMR data. Due to the high acidity, the sulfate group may appear as a sodium salt.

The remaining three carbon atoms $\mathrm{C}-15, \mathrm{C}-16$, and $\mathrm{C}-21$ were assigned using a 1,1-ADEQUATE correlation from $\mathrm{H}-17$ to $\mathrm{C}-16$ and HMBC correlations from $\mathrm{H}-17$ to $\mathrm{C}-15$ and $\mathrm{C}-21$ and $\mathrm{H}-22$ to C-21.

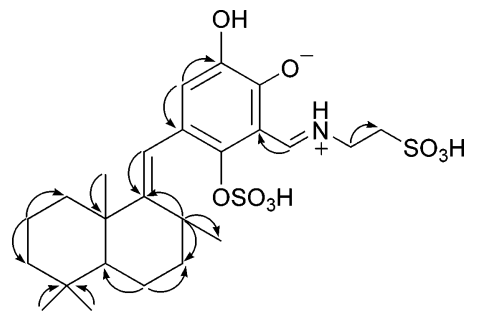

Figure 2. Selected 1,1-ADEQUATE correlations observed for siphonodictyal B1 (6).<smiles></smiles>

I<smiles>C=Cc1cc(O)c(OS(=O)(=O)O)c(C=O)c1O</smiles>

II<smiles>C=Cc1cc(O)c(O)c(C=O)c1OS(=O)(=O)O</smiles>

III
Figure 3. Possible constitutional proposals for the aromatic moiety of siphonodictyal B2 (7) (sum over all $\Delta \delta\left({ }^{13} \mathrm{C}\right.$ ); I $33.9 \mathrm{ppm}$, II 17.9 ppm, III 9.5 ppm).

The elucidation of the aromatic moiety of compound 7 was easier, because of an additional phenolic proton and improved separation of ${ }^{13} \mathrm{C}$ NMR chemical shifts for $\mathrm{C}-15$ and $\mathrm{C}-17$. The accurate mass of $\mathrm{m} / \mathrm{z} 437.1621[\mathrm{M}-\mathrm{H}]^{-}$indicated the molecular formula $\mathrm{C}_{22} \mathrm{H}_{29} \mathrm{O}_{7} \mathrm{~S}$. Under MS/MS conditions the loss of $\left[\mathrm{SO}_{3}\right]^{-}$ was observed, indicating a sulfate ester group. Similar NMR data for 6 and 7 indicated that the sesquiterpene moiety of these compounds was identical. HMBC correlations of the two phenolic protons from $\mathrm{OH}-18$ to $\mathrm{C}-17, \mathrm{C}-18$, and $\mathrm{C}-19$ and from $\mathrm{OH}-19$ to
C-18, C-19, C-20, and C-22 displayed two identical correlations, suggesting an ortho arrangement of the hydroxyl groups. An 1,1ADEQUATE correlation from $\mathrm{H}-17$ to $\mathrm{C}-18$ assigned the ortho position of $\mathrm{C}-17$ to $\mathrm{C}-18$. The three remaining quaternary carbon atoms could be elucidated because of $\mathrm{HMBC}$ correlations from $\mathrm{H}-17$ to C-16, C-18, C-19, and C-21, from H-22 to C-18, C-19, and C-20, and from $\mathrm{H}-15$ to C-17, C-19, C-20, and C-21. Position 16 was defined by an 1,1-ADEQUATE correlation from H-15 to C-16.

The differentiation of the three constitutional proposals with respect to the position of the sulfate is further supported by ${ }^{13} \mathrm{C}$ chemical shift analysis. An increment system based on Ragan's ${ }^{6}$ clearly favors proposal III as the correct constitution for the aromatic moiety of compound 7 (Figure 3). Substructure III is additionally supported by a strong ROESY correlation from $\mathrm{H}-17$ to $\mathrm{OH}-18$ and the mentioned HMBC correlations which clearly indicate the pyrrocatechol moiety for $\mathrm{OH}-18$ and $\mathrm{OH}-19$.

Siphonodictyal B3 (8) was identified by NMR data and its accurate mass, which indicated the molecular formula $\mathrm{C}_{22} \mathrm{H}_{29} \mathrm{O}_{10} \mathrm{~S}_{2}$. Comparison of $\delta\left({ }^{13} \mathrm{C}\right)$ data of $\mathbf{1}$ and $\mathbf{8}$ revealed an identical sesquiterpene moiety. MS/MS analysis showed a double loss of $\left[\mathrm{SO}_{3}\right]^{-}$, suggesting a double sulfation in the aromatic moiety. HMBC correlations from OH-19 to C-18, C-19, C-20, and C-22 established the position of the phenolic hydroxyl group at C-19. This is supported by a hydrogen bond between the carbonyl function and the phenolic hydroxyl group due to a downfield-shifted signal for $\mathrm{OH}-19$ in the ${ }^{1} \mathrm{H}$ NMR spectrum and the small line width. These results established a para constitution for the two sulfate ester groups at $\mathrm{C}-18$ and $\mathrm{C}-21$ according to constitutional proposal II (Figure 4). This result was confirmed by increment calculations (see Supporting Information). ${ }^{6}$

Corallidictyal C (9) and corallidictyal D (10) were found as minor metabolites and could be isolated only as a mixture like corallidictyal A (4) and corallidictyal B (5). As previously described for 4 and $5(3: 7),{ }^{4}$ the ratio of proton integrals for $\mathbf{9}$ and $\mathbf{1 0}$ is 3:5. The accurate mass of $\mathrm{m} / z 357.2053[\mathrm{M}-\mathrm{H}]^{-}$indicated the molecular 
<smiles>C=Cc1cc(O)c(OS(=O)(=O)O)c(C=O)c1OS(=O)(=O)O</smiles>

।

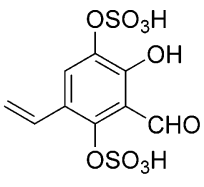

II



III
Figure 4. Possible constitutional proposals for the aromatic moiety of siphonodictyal B3 (8) (sum over all $\Delta \delta\left({ }^{13} \mathrm{C}\right.$ ); I $48.3 \mathrm{ppm}$, II 7.7 ppm, III 16.9 ppm).

formula $\mathrm{C}_{22} \mathrm{H}_{29} \mathrm{O}_{4}$. Comparison of spectroscopic data with $\mathbf{1}$ and 4/5 revealed an identical decalin moiety. In comparison to $\mathbf{1}$, the double bond between $\mathrm{C}-9$ and $\mathrm{C}-15$ and the proton signal for $\mathrm{OH}-$ 21 were missing. The aromatic moiety was elucidated using HMBC correlations. Similar to 7, both phenolic hydroxyl groups displayed two identical correlations, suggesting an ortho arrangement. The edited HSQC proved the existence of a methylene group at position 15 , which was supported by an upfield-shifted $\delta\left({ }^{13} \mathrm{C}\right)$ for $\mathrm{C}-15$ in comparison to $\mathbf{1}$. These arguments, in combination with a quaternary carbon at C-9, indicated a benzofurane structure for corallidictyals C (9) and D (10).

The configuration of the double bond between C-9 and C- 15 in 6, 7, and 8 was determined to be $E$ using ROEs from $\mathrm{H}-15$ to $\mathrm{H}-1$ and $\mathrm{H}-14$ as well as $\mathrm{H}-17$ to $\mathrm{H}-8$. A detailed analysis of the protonproton couplings and interproton distances was not possible because of the severe overlap of the involved protons $\mathrm{H}-1, \mathrm{H}-3, \mathrm{H}-5$, and $\mathrm{H}-7$. Therefore, a comparison of $\delta\left({ }^{13} \mathrm{C}\right)$ had to be used for elucidation of the configuration at $\mathrm{C}-5, \mathrm{C}-8$, and $\mathrm{C}-10$. The determination of the relative configuration of related compounds, for example, siphonodictyal B (1), spongiaquinone, ${ }^{7}$ and deoxyspongiaquinone, ${ }^{8}$ including a sesquiterpene moiety identical with that in $\mathbf{6}, \mathbf{7}$, and $\mathbf{8}$, is based on the comparison of spectroscopic data with 11-nordriman-9-one (12), which was obtained by ozonolysis of the natural products. Unfortunately, no assigned ${ }^{13} \mathrm{C}$ data were reported for $\mathbf{1 2}$, whereas for the epimeric form (C-8) ${ }^{13} \mathrm{C}$ shift values are available. ${ }^{9}$ The comparison of $\delta\left({ }^{13} \mathrm{C}\right)$ between the $\mathrm{C}-8$ epimer of $\mathbf{1 2}$ and the new compounds displayed very similar values, except for those at C-5. Measurements of siphonodictyal B (1) in DMSO- $d_{6}$ and $\mathrm{CDCl}_{3}$ revealed a solvent-dependent effect for the ${ }^{13} \mathrm{C}$ shift at C-5 (DMSO- $d_{6}: 49.0 \mathrm{ppm} ; \mathrm{CDCl}_{3}: 52.4 \mathrm{ppm}$ ), while the remaining values were very similar (Table 1 ). The trans-decalin moiety is further supported by the ${ }^{13} \mathrm{C}$ chemical shift difference of the geminal methyl groups at C-4 (12 ppm). This is caused by a 1,3-diaxial interaction with the methyl group at C-10. These results suggested an identical stereochemistry for compounds $\mathbf{6}, \mathbf{7}$, and $\mathbf{8}$ as published for siphonodictyal B (1). The configuration of C-8 was assigned by comparison of the ${ }^{13} \mathrm{C}$ shift for $\mathrm{C}-13$ with the synthetic precursor of siphonodictyal B (1). ${ }^{10}$ The configuration at C-8 was determined to be $S$ by comparing analogous values. For a variety of compounds with an identical sesquiterpene moiety $(S$ configuration of $\mathrm{C}-8$ ) the values for ${ }^{13} \mathrm{C}$ shifts at $\mathrm{C}-13$ are in a very similar range $(\sim 22 \mathrm{ppm}){ }^{8,11}$ The inversion of the configuration at $\mathrm{C}-8$ effected a change of the ${ }^{13} \mathrm{C}$ shift at $\mathrm{C}-13\left(\Delta \delta\left({ }^{13} \mathrm{C}\right)=7 \mathrm{ppm}\right)$, as was shown for chromazonarol and 8 -epichromazonarol. ${ }^{12}$

The relative configuration of corallidictyals C (9) and D (10) was elucidated on the basis of ROESY spectra. For corallidictyal D (10), a ROE from H-8 to H-15 was observed, but this ROE is missing in corallidictyal C (9), which confirmed the same configuration at C-9 as published for corallidictyal A/B (4/5). Furthermore, ROEs from $\mathrm{H}-8$ to $\mathrm{H}-14$ and missing ROEs from $\mathrm{H}-13$ to $\mathrm{H}-14$ in $\mathbf{9}$ and $\mathbf{1 0}$ revealed the $R$-configuration of the methyl group at C-13. The comparison of $\delta\left({ }^{13} \mathrm{C}\right)$ with $\mathbf{4}$ and $\mathbf{5}$ indicated an identical configuration at C-5 and C-10.

Siphonodictyol G (2) was identified by its high accurate mass and by comparison of spectroscopic data in the literature. ${ }^{2 b}$ Structure elucidation of the aromatic moiety was confirmed by a 1,1ADEQUATE experiment. Correlations from H-19 to C-18 and C-20, from H-21 to C-16 and C-20, and from H-22 to C-20 verified
Table 3. $\mathrm{DPPH}^{a}$ Radical-Scavenging Activities of Selected Compounds Compared to Ascorbic Acid

\begin{tabular}{lrr}
\hline & \multicolumn{2}{c}{$\%$ scavenging $^{b}$} \\
\cline { 2 - 3 } \multicolumn{1}{c}{ compound tested } & $200^{c}$ & \multicolumn{1}{c}{$40^{c}$} \\
\hline siphonodictyal B1 (6) & 80.8 & 23.5 \\
siphonodictyal B2 (7) & 88.8 & 25.3 \\
siphonodictyol G (2) & 39.8 & 2.6 \\
siphonodictyal G (11) & 32.2 & 5.9 \\
corallidictyal A/B (4/5) & 3.3 & 1.1 \\
ascorbic acid & 95.3 & 27.0 \\
\hline
\end{tabular}

${ }^{a} \mathrm{DPPH}=\alpha, \alpha$-diphenyl- $\beta$-picrylhydrazyl. ${ }^{b}$ Scavenging $\%=100$ - (A sample $\times 100 / A$ control), absorbance $(A)$ of sample and control measured at $517 \mathrm{~nm} .{ }^{c}$ Concentrations in $\mu \mathrm{mol} / \mathrm{L}$.

the proposed structure. In addition, a coupling constant of $1.8 \mathrm{~Hz}$ between $\mathrm{H}-19$ and $\mathrm{H}-21$ indicated a meta constitution for the two protons.

By the use of HPLC-MS screening, a metabolite (11) with the molecular formula $\mathrm{C}_{22} \mathrm{H}_{30} \mathrm{O}_{6} \mathrm{~S}$ and nine degrees of unsaturation was detected. Comparison of NMR spectra of siphonodictyol G (2) and this compound revealed an identical structure, but with a benzaldehyde group instead of a benzylic alcohol moiety. This was supported by one further degree of unsaturation and the downfieldshifted ${ }^{1} \mathrm{H} /{ }^{13} \mathrm{C}$ signal at position 22 in comparison to 2 . The substitution pattern in the aromatic moiety of siphonodictyal G (11) was identical to that in siphonodictyol G (2).

The hydroquinone structures of the isolated compounds suggested a potential radical-scavenging character. This was surveyed using the DPPH assay. Compounds that have a hydroquinone system, e.g., phlorotannins ${ }^{13}$ or meroterpenoids, ${ }^{14}$ usually show strong activities in this assay. For quinone systems this activity is not expected, because the highest oxidation state is already reached. The results revealed an activity for compounds $\mathbf{2 , ~ 6 , 7 , ~ a n d ~} \mathbf{1 1}$ and no activity for compounds $\mathbf{4 / 5}$ (see Table 3 ).

Siphonodictyal B2 (7) showed effects comparable to ascorbic acid. It is known that hydroquinone systems can take up an electron, which leads to the resulting phenoxyl radical. This process is included in oxidation and reduction of the corresponding hydroquinone and quinone. The activity of $\mathbf{2}$ and $\mathbf{1 1}$ and inactivity of 4/5 suggested that the intact aromatic system in conjunction with a phenolic function was a requirement for a radical-scavenging property. The strongest activity was observed for the orthohydroquinones 6 and 7, while compounds 2 and 11, with phenolic moieties, were less active.

The isolated compounds were further tested for antimicrobial activity against different Gram-positive and Gram-negative bacteria, yeasts, and fungi and for their capacity to inhibit cell proliferation of mouse fibroblasts. The results given in Table 4 showed activities in all assays, although there was low activity in antimicrobial assays against yeasts and Gram-negative bacteria. For the group of Gramnegative bacteria, activity was detected only against the cell wall defective Escherichia coli strain tolC. Only desulfated compounds were active, indicating a possible influence of sulfate ester groups on the bioactivity. The same pattern was observed for the pathogenic fungus Aspergillus fumigatus. All compounds except 2, 8, and 11 showed activity against Staphylococcus aureus, confirming the results of Sullivan et al. ${ }^{2 b}$ These results suggest that the different constituents of the aromatic moieties of $\mathbf{2 , 8}$, and $\mathbf{1 1}$ may have an impact on activity. The ortho-hydroquinone structure may be the active center of the molecules. It is likely that the hydroquinone is oxidized in the metabolism of the assay organisms to yield the more toxic ortho-quinone. The most active of the tested compounds were the corallidictyals A/B (4/5) and C/D (9/10). These compounds not only had the widest spectrum of antibiotic activity, but also showed a remarkable cytotoxic activity against the L929 mouse fibroblasts. To further investigate this cytotoxic effect, experiments were performed with $\mathbf{4 / 5}$ using a $\mathrm{PtK}_{2}$ potoroo kidney cell assay. Figure 5 shows $\mathrm{PtK}_{2}$ potoroo kidney cells that were stained by labeling a 
Table 4. Results of the Antimicrobial Assays and of a Cell Proliferation Assay with L929 Mouse Fibroblasts ${ }^{a}$

\begin{tabular}{|c|c|c|c|c|c|c|c|c|c|}
\hline & test organism & 1 & 2 & $4 / 5$ & 6 & 7 & 8 & $9 / 10$ & 11 \\
\hline \multirow[t]{3}{*}{ Gram-negative bacteria } & Escherichia coli tolC & 9 & 0 & 10 & 0 & 0 & 0 & 12 & 0 \\
\hline & Klebsiella pneumoniae & n.t. & 0 & 0 & 0 & 0 & 0 & n.t. & 0 \\
\hline & Pseudomonas aeruginosa & n.t. & 0 & 0 & 0 & 0 & 0 & n.t. & 0 \\
\hline \multirow[t]{3}{*}{ Gram-positive bacteria } & Micrococcus luteus & n.t. & 0 & 8 & 0 & 0 & 0 & n.t. & 0 \\
\hline & Mycobacterium phlei & n.t. & 0 & 12 & 0 & 0 & 0 & n.t. & 0 \\
\hline & Staphylococcus aureus & 12 & 0 & 12 & 12 & 13 & 0 & 13 & 0 \\
\hline \multirow{3}{*}{ yeasts } & Candida albicans & n.t. & 0 & 0 & 0 & 0 & 0 & n.t. & 0 \\
\hline & Hansenula anomala & n.t. & 0 & 7 & 0 & 0 & 0 & n.t. & 0 \\
\hline & Saccharomyces cerevisiae & 0 & 0 & 0 & 0 & 0 & 0 & 0 & 0 \\
\hline \multirow[t]{3}{*}{ filamentous fungi } & Aspergillus fumigatus & 15 & 0 & 14 & 0 & 0 & 0 & 19 & 0 \\
\hline & Botrytis cinerea & n.t. & $15^{b}$ & $20^{b}$ & $13^{b}$ & $15^{b}$ & 0 & n.t. & 0 \\
\hline & Pythium debaryanum & n.t. & 0 & $13^{b}$ & 0 & 0 & 0 & n.t. & 0 \\
\hline cytotoxic activity ${ }^{c}$ & L929 mouse fibroblasts & 0.2 & $>40$ & 0.08 & 10 & 6 & $>40$ & 0.1 & 10 \\
\hline
\end{tabular}

${ }^{a}$ Agar diffusion assays were carried out using paper disks of $6 \mathrm{~mm}$ diameter spotted with $20 \mu \mathrm{g}$ of the compound dissolved in methanol (diameter in $\mathrm{mm}$ of inhibition zones indicated). ${ }^{b}$ Incomplete inhibition zone, n.t.: not tested. ${ }^{c}$ Concentrations are given in $\mu \mathrm{g} / \mathrm{mL}$. Growth was measured using an MTT assay.
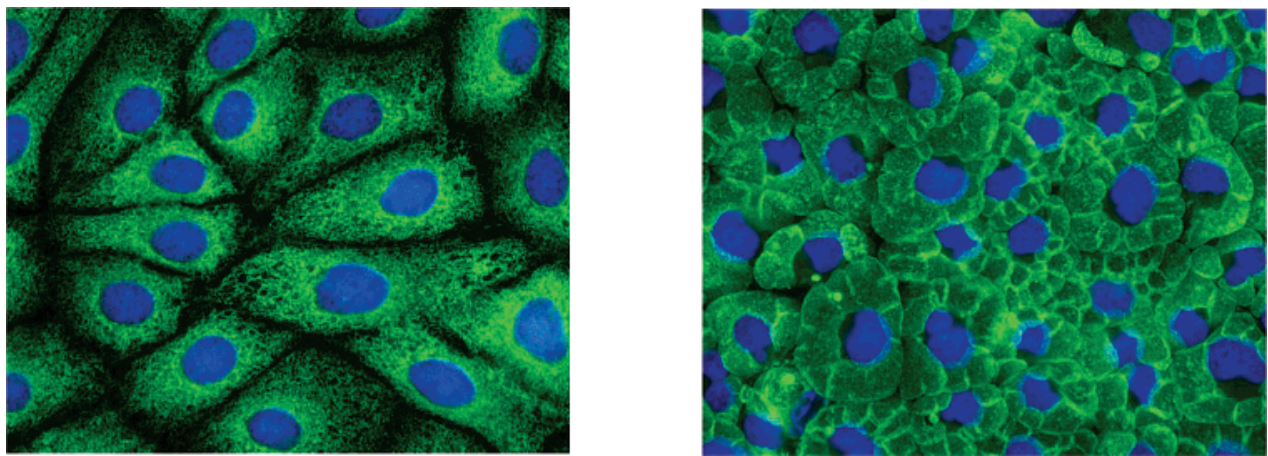

Figure 5. Influence of corallidictyal $\mathrm{A} / \mathrm{B}(\mathbf{4} / \mathbf{5})$ on $\mathrm{PtK}_{2}$ potoroo cells. Cells were stained for nuclei and ER structure. Cells that were incubated with $0.5 \mu \mathrm{g} / \mathrm{mL}$ overnight show vacuolizations within the ER that form a cushion-like pattern (right; untreated cells left).

marker protein of the endoplasmic reticulum. Cells treated with corallidictyals $A / B(\mathbf{4} / \mathbf{5})$ showed striking alterations of the inner membrane structure of the cytoplasm. As discussed previously, the quinone moieties may be the active part in Michael addition reactions that interfere with regulatory molecules in living cells. ${ }^{15}$ In addition to the quinone moiety of corallidictyals $A / B(4 / 5)$, the aldehyde moiety may play an important role in the cytotoxic activity of siphonodictyal G (11) as compared to siphonodictyol G (2).

Applying a more gentle extraction method than used in previously publications, ${ }^{2 \mathrm{a}, \mathrm{b}}$ the sulfated sesquiterpene-hydroquinones siphonodictyals B1 (6), B2 (7), B3 (8), and G (11) as well as corallidictyals $\mathrm{C}(\mathbf{9})$ and $\mathrm{D}(\mathbf{1 0})$ were isolated from $A$. coralliphagum growth form incrustans. For the first time, a systematic NMR assignment of the siphonodictyals was performed. The isolated compounds showed interesting biological activities, especially cytotoxic effects. Understanding the role these metabolites play in the ecology of A. coralliphagum, particularly their effects against sponge predators and the coral species this sponge attacks, will require additional biological assays and further analyses of the metabolites. The structure elucidation of the sulfated secondary metabolites of the growth form typica is under investigation. Preliminary results suggest that derivatives of siphonodictyal $\mathrm{E}$ are the main metabolites of this growth form.

\section{Experimental Section}

General Experimental Procedures. Optical rotation was measured with a Perkin-Elmer 214 polarimeter at $20{ }^{\circ} \mathrm{C}$. UV spectra were recorded with a DAD (Agilent) during HPLC analysis. IR spectra were recorded with a Bruker Equinox 55 spectrometer. ${ }^{1} \mathrm{H}$ NMR and ${ }^{13} \mathrm{C}$ NMR spectra were recorded on Bruker Avance 400 and 600 NMR spectrometers, all measured at 25 or $30^{\circ} \mathrm{C}$. The DQF- ${ }^{1} \mathrm{H},{ }^{1} \mathrm{H}-\mathrm{COSY}$, ${ }^{1} \mathrm{H},{ }^{13} \mathrm{C}-\mathrm{HSQC},{ }^{1} \mathrm{H},{ }^{13} \mathrm{C}-\mathrm{HMBC}, 1,1$-ADEQUATE, ${ }^{1} \mathrm{H},{ }^{15} \mathrm{~N}-\mathrm{HSQC},{ }^{1} \mathrm{H},{ }^{15} \mathrm{~N}-$ $\mathrm{HMBC}$, and ${ }^{1} \mathrm{H},{ }^{1} \mathrm{H}-\mathrm{ROESY}$ experiments were carried out using standard parameters. HPLC-MS analyses were performed with an Agilent 1100 HPLC system and a Bruker Daltonics microTOF ${ }_{L C}$ mass spectrometer.
Separation was achieved by a Waters $\mathrm{XTerra} \mathrm{RP}_{18}$ column $(3.0 \times 150$ $\mathrm{mm}, 3.5 \mu \mathrm{m})$ applying a $\mathrm{MeCN} / \mathrm{NH}_{4} \mathrm{OAc}(5 \mathrm{mM}$ in water) gradient $(0$ min: $20 \% \mathrm{MeCN} / 80 \% \mathrm{NH}_{4} \mathrm{OAc}$; $30 \mathrm{~min}: 100 \% \mathrm{MeCN} / 0 \% \mathrm{NH}_{4} \mathrm{OAc}$; 35 min: $100 \% \mathrm{MeCN} / 0 \% \mathrm{NH}_{4} \mathrm{OAc}$ ). UV detection was performed at a wavelength of $260 \mathrm{~nm}$. ESIMS/MS spectra were recorded with an Esquire 3000plus ion trap (Bruker Daltonics).

Animal Material. The sponge Aka coralliphagum was collected by scuba at San Salvador in the Bahamas (12-26 m depth, March 2001 and July 2003). The samples were immediately frozen after collection and kept at $-20{ }^{\circ} \mathrm{C}$ until extraction. The sponge material was identified as A. coralliphagum. A voucher is retained at the Zoological Museum, University of Amsterdam (ZMA POR. 17277).

Extraction and Isolation. The freeze-dried sponge samples of $A$. coralliphagum growth form incrustans $(134.12 \mathrm{~g})$ were crushed with a mill and extracted exhaustively with $\mathrm{MeOH}$ at RT under a $\mathrm{N}_{2}$ atmosphere over $24 \mathrm{~h}$ to yield $25.91 \mathrm{~g}$ of crude extract. The yelloworange-colored crude extract (4.32 g) of A. coralliphagum was purified by preparative $\mathrm{RP}_{18} \mathrm{HPLC}\left(\mathrm{MeCN} / \mathrm{H}_{2} \mathrm{O}\right.$ gradient) using a ProntoSIL Eurobond C18 column (VDS Optilab) $(250 \times 20 \mathrm{~mm}, 5 \mu \mathrm{m})$. Collected fractions were immediately freeze-dried to obtain 6 (366 $\mathrm{mg}, 0.273 \%$ of dry weight), 7 (73 mg, $0.054 \%$ of dry weight), 8 (35 mg, $0.026 \%$ of dry weight), 9/10 (29 mg, 0.022\% of dry weight), and $\mathbf{1 1}(20 \mathrm{mg}$, $0.015 \%$ of dry weight) as pure compounds. Freeze-dried sponge samples of the growth form typica were crushed with a mill and extracted exhaustively with $\mathrm{MeOH}$ at RT under a $\mathrm{N}_{2}$ atmosphere over $24 \mathrm{~h}$. The orange-colored crude extract was analyzed by HPLC-MS.

Siphonodictyal B (1): yellow powder; UV (DAD) $\lambda_{\max } 265,335$ $\mathrm{nm} ;{ }^{1} \mathrm{H}$ NMR data, see Table $2 ;{ }^{13} \mathrm{C}$ NMR data, see Table 1 ; HPLC/ $\mathrm{HR}(-)$ ESIMS $t_{\mathrm{R}}=29.4 \mathrm{~min}, \mathrm{~m} / \mathrm{z} 357.2044[\mathrm{M}-\mathrm{H}]^{-}$(calcd for $\mathrm{C}_{22} \mathrm{H}_{29} \mathrm{O}_{4}, m / z$ 357.2060, $\Delta m=4.5$ ).

Siphonodictyol G (2): light yellow powder; $[\alpha]_{\mathrm{D}}^{20}-40$ (c 0.398 , $\mathrm{MeOH}$ ); UV (DAD) $\lambda_{\max } 205,220$ (s), $280 \mathrm{~nm} ;{ }^{1} \mathrm{H}$ NMR data, see Table $2 ;{ }^{13} \mathrm{C}$ NMR data, see Table $1 ; \operatorname{HPLC} / \mathrm{HR}(-)$ ESIMS $t_{\mathrm{R}}=16.4$ min, $m / z 423.1823[\mathrm{M}-\mathrm{H}]^{-}\left(\right.$calcd for $\mathrm{C}_{22} \mathrm{H}_{31} \mathrm{O}_{6} \mathrm{~S}, \mathrm{~m} / \mathrm{z} 423.1836, \Delta m$ $=3.1$ ).

Corallidictyal A/B (4/5): yellow powder; UV (DAD) $\lambda_{\max } 265,325$ $\mathrm{nm} ;{ }^{1} \mathrm{H}$ NMR data, see Table $2 ;{ }^{13} \mathrm{C}$ NMR data, see Table 1; HPLC/ 
$\mathrm{HR}(-)$ ESIMS $t_{\mathrm{R}}=22.9 \mathrm{~min}, \mathrm{~m} / \mathrm{z} 355.1908[\mathrm{M}-\mathrm{H}]^{-}$(calcd for $\mathrm{C}_{22} \mathrm{H}_{27} \mathrm{O}_{4}, m / z$ 355.1904, $\left.\Delta m=1.1\right)$.

Siphonodictyal B1 (6): orange powder; $[\alpha]_{\mathrm{D}}^{20}-60(c)$ $\mathrm{MeOH}$ ); UV (DAD) $\lambda_{\max } 262,303$ (s), $440 \mathrm{~nm}$; IR (KBr) $v_{\max } 1648$, 1224, $1050 \mathrm{~cm}^{-1} ;{ }^{1} \mathrm{H}$ NMR data, see Table $2 ;{ }^{13} \mathrm{C}$ NMR data, see Table 1; HPLC/HR(-)ESIMS $t_{\mathrm{R}}=12.4 \mathrm{~min}, \mathrm{~m} / z, 544.1680[\mathrm{M}-\mathrm{H}]^{-}(\mathrm{calcd}$ for $\mathrm{C}_{24} \mathrm{H}_{34} \mathrm{NO}_{9} \mathrm{~S}_{2}, m / z$ 544.1669, $\Delta m=2.0$ ).

Siphonodictyal B2 (7): yellow powder; $[\alpha]_{\mathrm{D}}^{20}-76(c) 0.428$, $\mathrm{MeOH}$ ); UV (DAD) $\lambda_{\max } 240,370 \mathrm{~nm}$; IR (KBr) $v_{\max } 1647,1228,1052$ $\mathrm{cm}^{-1} ;{ }^{1} \mathrm{H}$ NMR data, see Table $2 ;{ }^{13} \mathrm{C}$ NMR data, see Table 1 ; HPLC/ $\mathrm{HR}(-)$ ESIMS $t_{\mathrm{R}}=17.1 \mathrm{~min}, \mathrm{~m} / \mathrm{z} 437.1621[\mathrm{M}-\mathrm{H}]^{-}$(calcd for $\mathrm{C}_{22} \mathrm{H}_{29} \mathrm{O}_{7} \mathrm{~S}, m / z$ 437.1629, $\left.\Delta m=1.7\right)$.

Siphonodictyal B3 (8): yellow powder; UV (DAD) $\lambda_{\max } 238,357$ nm; ${ }^{1} \mathrm{H}$ NMR data, see Table $2 ;{ }^{13} \mathrm{C}$ NMR data, see Table 1 ; HPLC/ $\mathrm{HR}(-)$ ESIMS $t_{\mathrm{R}}=11.9 \mathrm{~min}, \mathrm{~m} / z 258.0560[\mathrm{M}-2 \mathrm{H}]^{2-}(\mathrm{calcd}$ for $\mathrm{C}_{22} \mathrm{H}_{28} \mathrm{O}_{10} \mathrm{~S}_{2}, m / z$ 258.0556, $\Delta m=1.2$ ).

Corallidictyal C/D (9/10): yellow powder; UV (DAD) $\lambda_{\max } 220$, 280, $410 \mathrm{~nm} ;{ }^{1} \mathrm{H}$ NMR data, see Table $2 ;{ }^{13} \mathrm{C}$ NMR data, see Table 1; HPLC/HR(-)ESIMS $t_{\mathrm{R}}=29.6 \mathrm{~min}, \mathrm{~m} / z, 357.2053[\mathrm{M}-\mathrm{H}]^{-}(\mathrm{calcd}$ for $\mathrm{C}_{22} \mathrm{H}_{29} \mathrm{O}_{4}, m / z, 357.2060, \Delta m=1.9$ ).

Siphonodictyal G (11): light yellow powder; UV (DAD) $\lambda_{\max } 220$, 268, $314 \mathrm{~nm} ;{ }^{1} \mathrm{H}$ NMR data, see Table $2 ;{ }^{13} \mathrm{C}$ NMR data, see Table 1; HPLC/HR(-)ESIMS $t_{\mathrm{R}}=19.4 \mathrm{~min}, \mathrm{~m} / z$, $421.1666[\mathrm{M}-\mathrm{H}]^{-}(\mathrm{calcd}$ for $\mathrm{C}_{22} \mathrm{H}_{29} \mathrm{O}_{6} \mathrm{~S}, \mathrm{~m} / \mathrm{z}$ 421.1679, $\Delta m=3.3$ ).

Hydrolysis of Siphonodictyal B1 (6). A $0.6 \mathrm{mg}$ sample of siphonodictyal B1 (6) was dissolved in $100 \mu \mathrm{L}$ of acetic acid (10\%) and incubated for $1 \mathrm{~h}$ at RT. Then $5 \mu \mathrm{L}$ of the test solution and a taurine standard $\left(1 \mathrm{mg} / \mathrm{mL}\right.$ in $\left.\mathrm{H}_{2} \mathrm{O}\right)$ were coated on a Si TLC plate $(\mathrm{Si}$ gel 60 , Merck). The plate was developed with butan-1-ol/acetic acid/ $\mathrm{H}_{2} \mathrm{O}(80 / 20 / 20)$ as mobile phase. Detection was performed using the ninhydrin reagent. The $R_{f}$ for taurine was 0.26 .

$\alpha, \alpha$-Diphenyl- $\beta$-picrylhydrazyl (DPPH) Assay. The assay was performed using a modification of a previously described method. ${ }^{14}$ For UV spectroscopic measurements half microcells were used. To 1000 $\mu \mathrm{L}$ of each sample at different concentrations $(200$ and $40 \mu \mathrm{M})$ in $\mathrm{EtOH}$ were added $250 \mu \mathrm{L}$ of DPPH $(1 \mathrm{mM})$ in EtOH and $750 \mu \mathrm{L}$ of EtOH. The resultant mixture was briefly shaken and maintained at RT in the dark for $30 \mathrm{~min}$. At the end of this time, the absorbance of the mixture was measured at $517 \mathrm{~nm}$, using a UV spectrometer. The calculations were performed similarly to literature methods. ${ }^{14}$

Antimicrobial Assay. Antimicrobial activities were determined by agar diffusion tests using paper disks of $6 \mathrm{~mm}$ diameter soaked with $20 \mu \mathrm{L}$ of the test compound in $\mathrm{MeOH}(1 \mathrm{mg} / \mathrm{mL})$. The microorganisms were obtained from the HZI collection, grown on standard media, and cultured in liquid agar medium to a final OD of 0.01 (bacteria) or 0.1 (yeasts). Spores of fungi were collected from well-grown Petri dishes, which were rinsed with $10 \mathrm{~mL}$ of sterile $\mathrm{H}_{2} \mathrm{O}$. One milliliter of the spore suspension was added to $100 \mathrm{~mL}$ of molten agar medium. Plates were incubated at $30^{\circ} \mathrm{C}$, and the diameters of resulting inhibition zones were measured after 1 and 2 days.

Cell Proliferation Assay. L929 mouse fibroblasts were obtained from the Deutsche Sammlung von Mikroorganismen und Zellkulturen (DSMZ) and cultivated at $37{ }^{\circ} \mathrm{C}$ and $10 \% \mathrm{CO}_{2}$ in DME medium (high glucose) supplemented with $10 \%$ fetal calf serum. Cell culture reagents were purchased from Life Technologies Inc. (GIBCO BRL). Growth inhibition was measured in microtiter plates. Aliquots of $120 \mu \mathrm{L}$ of the suspended cells ( $50000 / \mathrm{mL}$ ) were added to $60 \mu \mathrm{L}$ of serial dilutions of the test compounds. After 5 days the growth was determined using the MTT assay. ${ }^{16}$

Cell Staining. PtK ${ }_{2}$ cells (ATCC CCL-56) grown on glass coverslips were fixed with cold $\left(-20{ }^{\circ} \mathrm{C}\right) \mathrm{MeOH} /$ acetone $(1: 1)$ for $10 \mathrm{~min}$, incubated with a primary antibody against GRP-94 (1:1000; Affinity Bioreagents) and then with a secondary Alexa Fluor 488 goat anti-rat IgG antibody ( $1 \mu \mathrm{g} / \mathrm{mL}$; Molecular Probes), and mounted in ProLong Antifade Gold (Molecular Probes), which included DAPI to stain the nuclei.

Acknowledgment. We would like to thank B. Hinkelmann (HZI, Braunschweig) for performing the bioassays, C. Timm (Universität Frankfurt) for measuring optical rotations, R. W. M. van Soest (University of Amsterdam) for sponge identification, and K. Seifert (Universität Bayreuth) for providing synthetic precursors of siphonodictyal B.

Supporting Information Available: 2D NMR data, 1D ${ }^{1} \mathrm{H}$ and ${ }^{13} \mathrm{C}$ NMR spectra of siphonodictyals B1 (6) and B2 (7), ${ }^{1} \mathrm{H},{ }^{13} \mathrm{C}$ HMBC spectrum of siphonodictyal B1 (6), MS/MS spectra of siphonodictyals B1 (6) and B2 (7), and increment calculations. This material is available free of charge via the Internet at http://pubs.acs.org.

\section{References and Notes}

(1) Rützler, K. Smithsonian Contrib. Zool. 1971, 77, 1-37.

(2) (a) Sullivan, B.; Djura, P.; McIntyre, D. E.; Faulkner, D. J. Tetrahedron 1981, 37, 979-982. (b) Sullivan, B. W.; Faulkner, D. J.; Matsumoto, G. K.; He, C. H.; Clardy, J. J. Org. Chem. 1986, 51, 4568-4573. (c) Mukku, V. J. R. V.; Edrada, R. A.; Schmitz, F. J.; Shanks, M. K.; Chaudhuri, B.; Fabbro, D. J. Nat. Prod. 2003, 66, 686-689.

(3) Metzger, K.; Rehberger, P. A.; Erben, G.; Lehmann, W. D. Anal. Chem. 1995, 67, 4178-4183.

(4) Chan, J. A.; Freyer, A. J.; Carte, B. K.; Hemling, M. E.; Hofmann, G. A.; Mattern, M. R.; Mentzer, M. A.; Westley, J. W. J. Nat. Prod. 1994, 57, 1543-1548.

(5) Pretsch, E.; Bühlmann, P.; Affolter, C.; Badertscher, M. Spektroskopische Daten zur Strukturaufklärung organischer Verbindungen; Springer: Berlin, 2001.

(6) Ragan, M. A. Can. J. Chem. 1978, 56, 2681-2685.

(7) Kazlauskas, R.; Murphy, P. T.; Warren, R. G.; Wells, R. J.; Blount, J. F. Aust. J. Chem. 1978, 31, 2685-2697.

(8) Urban, S.; Capon, R. J. Aust. J. Chem. 1996, 49, 611-615.

(9) Dastlik, K. A.; Ghisalberti, E. L.; Skelton, B. W.; White, A. H. Aust. J. Chem. 1991, 44, 123-127.

(10) Bernet, A.; Seifert, K. Helv. Chim. Acta 2006, 89, 784-796.

(11) Bassett, S.; Ovenden, S. P. B.; Gable, R. W.; Capon, R. J. Aust. J. Chem. 1997, 50, 1137-1143.

(12) Djura, P.; Stierle, D. B.; Sullivan, B.; Faulkner, D. J.; Arnold, E.; Clardy, J. J. Org. Chem. 1980, 45, 1435-1441

(13) Kang, H. S.; Chung, H. Y.; Jung, J. H.; Son, B. W.; Choi, J. S. Chem. Pharm. Bull. 2003, 51, 1012-1014.

(14) Fisch, K. M.; Böhm, V.; Wright, A. D.; König, G. M. J. Nat. Prod. 2003, 66, 968-975.

(15) Monti, M. C.; Casapullo, A.; Santomauro, C.; D'Auria, M. V.; Riccio, R.; Gomez-Paloma, L. ChemBioChem 2006, 7, 971-980.

(16) Mosmann, T. J. Immunol. Methods 1983, 65, 55-63.

NP0603018 